\title{
PITUITARY HORMONE-PRODUCING CELLS AFTER ESTRADIOL APPLICATION IN RAT MODELS OF MENOPAUSE
}

Verica Milošević and Vladimir Ajdžanović

Department of Cytology, Institute for Biological Research “Siniša Stanković”, University of Belgrade, 11060 Belgrade, Serbia

\author{
HORMON-PRODUKUJUĆE ĆELIJE HIPOFIZE \\ NAKON PRIMENE ESTRADIOLA U ANIMALNOM MODELU \\ MENOPAUZE \\ Verica Milošević i Vladimir Ajdžanović \\ Odsek za citologiju, Institut za biološka istraživanja "Siniša Stanković”, Univerzitet u Beogradu, 11060 Beograd, Srbija
}

\section{ABSTRACT}

Female ageing represents the biological process of structural and functional changes in endocrine cells and tissues, as well as in pituitary hormone-producing cells. In addition to the hypothalamic releasing hormones, estradiol plays a significant role in the regulation of the synthesis/secretion of pituitary hormones and is still used therapeutically for menopausal symptoms. The effects of ageing or ovariectomy and synthetic estradiol application under these circumstances were evaluated in pituitary hormone-producing cells of female rats (animal models of menopause); i.e., the following cells were observed: gonadotropes (FSH and $L H)$, thyrotropes (TSH), somatotropes (GH), mammotropes (PRL) and corticotropes (ACTH). The cells were immunostained and histologically analysed. The ELISA method was used for hormonal analyses. Ageing was found to cause diverse, commonly reductive changes regarding the volume, number and secretion of menopausal rat pituitary hormone-producing cells, except for PRL cells that exhibit significantly increased numbers and intensified secretion. After the treatment of middle-aged female rats with estradiol, the absolute and relative pituitary weights significantly increased in comparison with the control females. Histological parameters such as the cell and volume density of PRL and ACTH cells were significantly increased compared with the control values. The mentioned parameters of FSH, LH, GH, and occasionally TSH cells after estradiol treatment significantly decreased in comparison with the controls. The corresponding hormone levels followed the changes in the histological parameters. These data indicate that the application of estradiol to menopausal females may specifically, in two directions, modify the histological characteristics and secretory activities of different pituitary-hormone producing cells.

Key words: female rat, middle age, pituitary cells, estradiol.

\section{SAŽETAK}

Starenje kod ženskog pola je biološki proces tokom kojeg dolazi do promena u strukturi i funkciji endokrinih ćelija $i$ tkiva, a posebnu osetljivost ispoljavaju hipofizne hormonprodukujuće ćelije. Pored oslobadajućih hormona hipotalamusa $i$ estradiol ostvaruje zapaženu ulogu u regulaciji sinteze $i$ sekrecije hipofiznih hormona, a još uvek se koristi u terapiji menopauzalnih tegoba. Efekti starenja ili ovarijektomije, kao i primene sintetskog estradiola pod tim okolnostima su ispitivani na hormon-produkujućim ćelijama hipofize ženki pacova srednjeg doba (animalni modeli menopauze) $i$ to: gonadotropima (FSH $i$ LH), tirotropima (TSH), somatotropima (GH), mamotropima (PRL) i kortikotropima (ACTH). Sve ćelije su imunohistohemijski bojene $i$ histološki analizirane, dok je za određivanje nivoa hormona u krvi korišćena ELISA metoda. Utvrdeno je da starenje prouzrokuje različite, uglavnom reduktivne promene volumena, broja i sekrecije hormon-produkujućih ćelija hipofize u našim animalnim modelima menopauze, izuzev na primeru PRL ćelija čiji je broj značajno povećan, a sekrecija intenzivirana. Posle tretmana ženki pacova srednjeg doba estradiolom apsolutna i relativna masa hipofize je značajno povećana u poređenju sa kontrolnim ženkama. Histološki parametri poput volumena ćelija $i$ volumenske gustine PRL i ACTH ćelija su značajno povećani u poređenju sa kontrolnim vrednostima. Sa druge strane, pomenuti parametri u FSH, LH i GH, a u izvesnim slučajevima i TSH ćelijama su značajno smanjeni nakon tretmana estradiolom, u poređenju sa kontrolama. Koncentracije odgovarajućih hormona u krvi su pratile navedene promene histoloških parametara. Ova zapažanja ukazuju da estradiol davan menopauzalnim jedinkama ženskog pola može na specifičan način, dvosmerno, modifikovati histološke karakteristike i sekretornu aktivnost različitih hormon-produkujućih ćelija hipofize.

Ključne reči: ženke pacova, srednje doba, hipofizne celije, estradiol 


\section{INTRODUCTION}

Endocrine function realisation is achieved through the multi-level systemic organisation, implying the participation of the hypothalamus, pituitary gland, immune system and various target endocrine organs and tissues. Therefore, the pituitary gland represents the entity of special interest because it orchestrates the immuno-neuro-endocrine interactions by the means of neuronal, hormonal, paracrine, juxtacrine and autocrine communication (1-2). The anterior part of the gland consists of several types of hormone-producing cells (gonadotropes - LH and FSH, thyrotropes - TSH, somatotropes - GH, mammotropes - PRL and corticotropes - ACTH), as well as folliculo-stellate non-hormone producing cells (3). Considerable interest has permanently been generated regarding hypothalamo-pituitary age-related changes. The most common anterior pituitary morphologic lesions in ageing involve some hyperplasia or adenoma (4), which are pathologies that are strongly linked to reproductive system function decline (5). Pertinent to this decline, ovarian follicular depletion in ageing females, followed by a

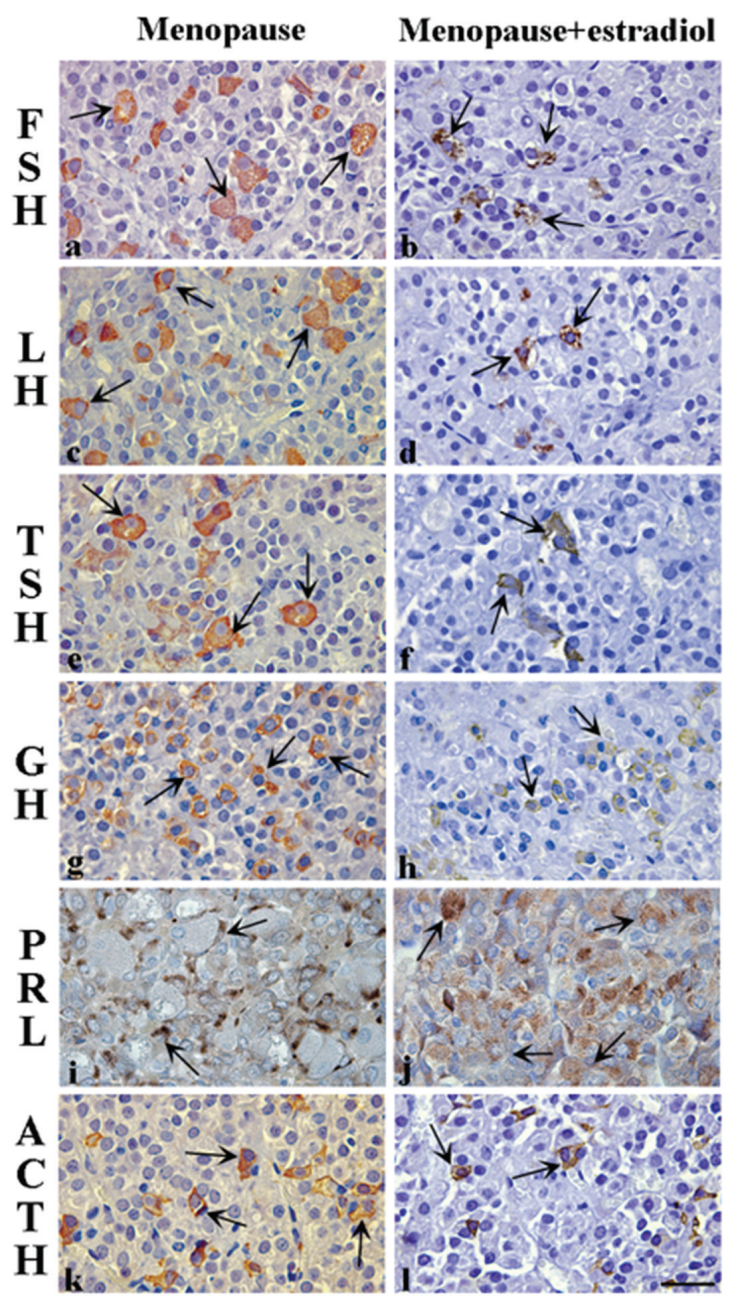

Figure 1. Immunohistochemically labelled pituitary hormone-producing cells in menopausal (a - FSH; c - LH, e - TSH, g - GH, i - PRL and k - ACTH) and estradiol-treated menopausal (b - FSH, d - LH, f - TSH, $\mathrm{h}-\mathrm{GH}, \mathrm{j}-\mathrm{PRL}$ and $\mathrm{l}-\mathrm{ACTH}$ ) female rats. Peroxidase-antiperoxidase method, $\operatorname{bar}=16 \mu \mathrm{m}$. decrease in circulating estradiol, is a critical factor triggering the menopausal transition (6), along with the distinctive changes at the level of the hypothalamus and anterior pituitary hormone-producing cells in the same individuals (7-8). In support of the latter, it was observed that the LH response to $\mathrm{GnRH}$ is decreased in older females compared with young females (7). Simultaneously, alterations in some other hormone-producing cell populations were also found in ageing female rats and women (5, 9-11). Despite some risks (12), estradiol replacement represents the classical therapeutic approach in the prevention of health problems due to ovarian hormone deficiency $(13,14)$. Various animal models have been developed to define the space for problematising the multiple morphofunctional changes during menopause, as well as to solve the present controversies regarding the application of estradiol in humans. Our experimental work in the field implied the usage of intact middle-aged (14 months old) or ovariectomised adult (3 months old) Wistar female rats, for which the pituitary histological and hormone secreting studies had a central role (10,11, 15-18). Herein, we aim to present the accumulated data regarding the various populations of anterior pituitary hormone-producing cells in our animal models of menopause and in related studies, as well as to elaborate the observed effects of synthetic estradiol application in these experimental studies.

\section{Menopausal rat pituitary hormone-producing cells}

Ageing is associated with a myriad of anatomical and functional changes of the endocrine glands, in the last instance as a result of programmed cell death and also as a consequence of autoimmune-mediated destruction or neoplastic transformation of the glandular tissue (19). Commonly, ageing represents the critical biological period for the control of gene expression and secretory activity in various endocrine cells and tissues, as well as in the entire hormone-producing cell pool in the pituitary gland $(5,20,21)$. Female ageing has been our research focus for years, and we exploited intact or ovariectomised female rats as a good menopausal model. The absolute and relative pituitary weights in our models significantly increased by $16.2 \%$ and $14.0 \%$, respectively, compared with those of intact adult female rats (22).

As mentioned previously, gonadotropes are subjected to substantial changes with reproductive ageing in women. Our histological analysis of FSH and LH cells in middle-aged female rats showed that they were both ovoid and polyhedral in shape, occurred individually or more frequently in clusters, and established close contact with blood vessels (Figure $1 \mathrm{a}, \mathrm{c}$ ) (15). Their nuclei appeared to be round, vesicular and mostly eccentric (Figure $1 \mathrm{a}, \mathrm{c}$ ) (23). In middle-aged female rats, the volume of FSH cells was $1375 \mu^{3}$, and the volume of LH cells amounted to $998 \mu \mathrm{m}^{3}$. The number of immunolabeled FSH and LH cells per unit area $\left(\mathrm{mm}^{2}\right)$ was 78 and 142, respectively (23). Ultrastructural investigations showed that the gonadotropes had well-developed rough endoplasmic reticula (RER) and Golgi complexes (4). Secretory granules in female gonadotropes were spherical or slightly irregular with a small 
diameter (200-250 nm) (24). Plasma levels of FSH and LH in our middle-aged female rats were $3.67 \mathrm{mU} / \mathrm{L}$ and 537.30 $\mathrm{mU} / \mathrm{L}$, respectively (15). In middle-aged female rats, changes in pulsatile LH secretion were observed, whereas gonadotrophin-releasing hormone ( $\mathrm{GnRH})$ could not be detected in the peripheral plasma. Therefore, LH may be used as an indirect index of GnRH secretion in this age range (25).

TSH cells in middle-aged female rats from our experiments were mainly localised in the ventral or middle portion of the anterior pituitary gland (10). These cells adopted a variety of shapes (round, polyhedral or irregular) and had an intensely immunostained cytoplasm (Figure $1 \mathrm{e}$ ). Their volume density amounted to approximately $15 \%$ (10). Specifically, the number of TSH cells in middle-aged female rats per unit area $\left(\mathrm{mm}^{2}\right)$ was $110(10)$, and their volume decreased with age (26). The observed reduction of TSH activity in middle-aged female rats is associated with its large molecular form accumulating in the pituitary gland and in blood (27).

Immunohistochemical studies identified GH cells in middle-aged female rat pituitary glands having ovoid to pyramidal shapes with a spherical, centrally located nucleus. These cells were uniformly distributed throughout the gland (Figure $1 \mathrm{~g})(18,28)$. In our model of menopause, GH cells were usually found situated along the sinusoid capillaries (18). In terms of absolute values, the cellular and nuclear volumes of the GH cells, and their relative volume density were 1215 $\mu \mathrm{m}^{3}, 61 \mu \mathrm{m}^{3}$ and $28 \%$, respectively (29). Morphological analysis of the $\mathrm{GH}$ cells revealed that their heterogeneity rises in aged females (30), whereas the number of type II and III of GH cells increased with ageing (31). Namely, the type II GH cells contained large and small secretory granules, whereas the type III GH cells contained only small secretory granules (28). At the ultrastructural level, the RER were found disposed in parallel arrays, and the Golgi complex was moderately developed. Lysosomes that were occasionally observed in GH cells of acyclic female rats $(4,28,32)$ demonstrated that the $\mathrm{GH}$ secretion declines with ageing and the GH-mRNA content decreases due to diminished transcriptional activity of the adequate genes (33). The serum GH level decreased in middle-aged female rats, which is explained by the increased release of somatostatin and the decreased release of growth hormone-releasing hormone (GHRH) from the hypothalamus (34), as well as with a reduced pituitary responsiveness to GHRH stimulation (35). In young female rats, the blood $\mathrm{GH}$ levels were significantly higher than those of middleaged females, whereas the amplitude of GH pulsatile release was lower in the middle-aged rats compared with the young rats (34). In our model of ovariectomised female rats, the GH levels significantly decreased, by $75.8 \%$, compared with the intact controls (22).

In the middle-aged female rat pituitary glands we examined, immunohistochemically labelled PRL cells were polygonal, elongated in shape, had a spherical eccentrically located nucleus and and were sporadically distributed in the anteriorventral portion of the gland (Figure 1 i) (11). We observed that the cellular and nuclear volumes of the PRL cells, and their relative volume density in this animal model of menopause were $1180 \mu \mathrm{m}^{3}, 124 \mu \mathrm{m}^{3}$ and $35.8 \%$, respectively (29). Immuno-electron-microscopical studies showed that the PRL cells have abundant RER and a prominent Golgi complex, which contains ovoid or markedly pleomorphic electron-dense secretory granules (4). Importantly, rat PRL cells are divided into three subtypes based on the size of the granules (31). Type I cells contain large, irregularly shaped secretory granules (300$700 \mathrm{~nm})$, type II have spherical granules $(150-250 \mathrm{~nm})$, and type III contain some small round granules (of $100 \mathrm{~nm}$ ) (31). A significant increase in the number of PRL cells and their storage secretion was observed in middle-aged female rats by Takahashi et al. (1984) and Itoh at al. (2001), who investigated their pituitary morphophysiology $(36,37)$. Takahashi and Kawashima (1987) observed a significant age-related increase of the DNA content in PRL cells in rats of both sexes; however, this increase was more conspicuous in the females than in the males (38). Interestingly, age-related differences were significant in the relative proportion of each subtype of PRL cells (28). Namely, with age, the number of PRL cells with large secretory granules (type I) (31) and the concentration of PRL in the blood of female rats increased (5). Ovariectomy decreased the volume density of type I PRL cells by $32 \%$ but increased the same parameter of type II PRL cells by $52 \%$ and of type III by $16 \%$ (28). In ovariectomised female rats, the PRL blood levels remain elevated (28).

In our menopausal female rats, immunohistochemically labelled pituitary ACTH cells were stellate in shape, possessed cytoplasmatic processes amongst neighbouring cells and resided between the capillaries (Figure $1 \mathrm{k}$ ) (17). The nuclei followed the cell shape (Figure $1 \mathrm{k}$ ) (17). Compared to the same cell phenotype in adult female rats, their localisation and shape did not significantly change (39). In other studies of female rat ageing, electron microscopy analyses of ACTH cells demonstrated that the secretory granules are usually numerous, spherical or irregularly shaped (40) and have small secretory granules of (150-200 nm) distributed mainly at the periphery of the cytoplasm (4). Additionally, the RER, Golgi complex and mitochondria appear to be near the nucleus (41). Histological and ultrastructural changes annotated at the level of ACTH cells during ageing generally decrease the sensitivity of the hypothalamo-pituitary system to glucocorticoid negative feedback (42).

\section{The effects of estradiol application on pituitary hor- mone-producing cells in menopausal rats}

The synthesis and secretion of pituitary hormones is centrally regulated by hypothalamic-releasing hormones; however, they are also secreted by some other peripheral hormones. Among other things, estradiol is considerably involved in the control of various pituitary hormone-producing cells in female rats $(22,23,28,43)$. Namely, the presence of estradiol in the pituitary pars distalis was observed in the nuclei of all of the hormone producing cells, including acidophils, basophils and chromophobes (44). We have demonstrated previously that multiple estradiol doses administered to middle-aged female rats increase the number of chromophobe and PRL cells 
$(35,45)$. Finally, estradiol replacement represents the classical therapeutic approach in the prevention of menopausal problems, although manifesting some risks (12-14). We used the above-mentioned menopausal rat models to critically evaluate the effects of synthetic estradiol application, and the following pituitary hormone-producing cell changes were of special interest. Primarily, the absolute and relative pituitary weights in estradiol-treated middle-aged female rats significantly increased by $110 \%$ and $123 \%$, respectively, in comparison with the control female rats (11).

The extensive analysis showed that the volume and volume density of FSH cells, and the FSH blood levels in middleaged female rats treated with estradiol-dipropionate (EDP) significantly decreased by $35 \%, 65 \%$ and $46 \%$, respectively, in comparison with the control values $(15,46)$. In this animal model, the above-mentioned parameters of LH cells significantly decreased by $13 \%, 54 \%$ and $55 \%$, respectively, compared with the corresponding control values $(15,46)$. After multiple EDP treatments, the FSH and LH cells of middle-aged females were smaller and pycnotic and exhibited darker immunohistochemical staining in comparison with the untreated controls; however, their shape and distribution were not significantly altered (Figure $1 \mathrm{~b}, \mathrm{~d})(15,23)$. The numbers of FSH and LH cells per $\mathrm{mm}^{2}$ significantly decreased after treatment with EDP in the same model by $54 \%$ and $55 \%$, respectively, compared with the control females (23). In ovariectomised rats treated with EDP, the number of FSH cells per $\mathrm{mm}^{2}$ was 6-fold, and the LH cells exhibited a 4-fold decrease in comparison with the control values (15). These reduced parameters of the gonadotropes, reflecting, inter alia, their decreased content of stored FSH and LH, suggest the suppression of their synthetic activity after EDP treatment (45).

In middle-aged female rats treated with EDP, the immunopositive TSH cells were pycnotic and darkly stained (Figure 1 f) (10). In the animal model of menopause we used, the volume and volume density of the TSH cells significantly decreased after treatment with EDP by $44 \%$ and $67 \%$, respectively, in comparison with the control females (10). In contrast, the relative cellular and nuclear volumes of TSH cells increased (by $7 \%$ and $30 \%$, respectively) in ovariectomised female rats treated with EDP compared with the control intact females (47). The observed differences in the immunohistomorphometric characteristics of TSH cells in intact and ovariectomised female rats treated with EDP may be the result of different administered estradiol doses.

In our EDP-treated menopausal rats, the immunohistochemically stained pituitary GH cells were smaller and irregularly shaped and possessed a strong cytoplasmatic immuno-signal compared with the controls (Figure $1 \mathrm{~h}$ ) (18). In these animals, the cellular and nuclear volumes, and the relative volume density of the $\mathrm{GH}$ cells significantly decreased $72 \%, 11 \%$ and $86 \%$, respectively, compared with the control menopausal females (29). We also observed that estradiol inhibits GH secretion up to $65 \%(28,29)$, which reduces sensitivity to GHRH (35). Mooradian (1993) suggested an age-related decrease in the number of pituitary oestrogen receptors (19). Takahashi (1992) demonstrated that estradiol increases the percentage of type II and III GH cells (31). These cell types contain small secretory granules, a pronounced characteristic of the older rat population (31), which may support our results. Additionally, the GH blood levels after EDP treatment in ovariectomised female rats increased by $45 \%$ compared with intact female rats (21), indicating the significance of the removal of the ovaries the outcome of $\mathrm{GH}$ secretion.

An increase in the pituitary weight after estradiol treatment was previously observed and is the consequence of PRL cell proliferation (48). Murai and Ben-Jonathan (1990) postulated that estradiol plays a crucial role in the release of PRL (49). The pituitary PRL cells in middle-aged female rats after multiple treatments with the EDP are larger in size, irregularly shaped and more intensely immunostained compared with the controls (Figure $1 j$ ) (11). The treatment of female middle-aged rats with EDP significantly increases the immunohistomorphometric parameters of their PRL cells, especially their volume density $(11,28,29)$. Furthermore, estradiol application increased the percentage of PRL cells with large secretory granules (type I) and decreased the percentages of type II and III cells (31). The observed increase was consistent with higher serum $(11,29)$ and pituitary PRL levels (50) in rats, which is the biochemical data also found in menopausal women (51). The described changes were attributed to the reduction of hypothalamic dopamine activity (4). Treatment of ovariectomised, middle-aged female rats with $17 \beta$-estradiol significantly increased the volume density of the PRL cells, of which the most numerous were type I cells, by $160 \%$ compared with the control females (28).

Immunohistochemical analysis of ACTH cells in our middle-aged female rats treated with EDP showed that neither their shape nor their localisation significantly changed in comparison with the controls; however, the ACTH cells appeared less intensely immunostained (Figure 1 l) (17). In parallel, EDP application in the same model significantly increased the volume and volume density of ACTH cells by $10 \%$ and $43 \%$, respectively, in comparison with the control females (17).

\section{CONCLUSIONS}

Our observations of various histological and hormone secreting changes in the various hormone-producing cells in the ageing or ovariectomised female pituitary gland, as well as after synthetic estradiol application, are based on the exploitation of the adequate animal models of menopause. We have found that ageing causes diverse, commonly reductive changes regarding the volume, number and secretion of menopausal rat pituitary hormone-producing cells, except for PRL cells that manifest increased number and intensified secretion. As expected, after the treatment of middleaged female rats with estradiol, the absolute and relative pituitary weights significantly increased in comparison with the control females. Histological parameters such as the cell and volume density of PRL and ACTH cells significantly increased compared with control values. In contrast, the 
mentioned parameters of FSH, LH, GH, and occasionally TSH cells after estradiol treatment significantly decreased in comparison with the controls. Notably, ovariectomy and estradiol treatment in adult female rats caused the increase of the TSH cell histological parameters. In general, the corresponding hormone level alterations followed the observed changes of histological parameters in our models. These data indicate that the application of estradiol to menopausal females may specifically, in two directions, modify the histological characteristics and secretory activities of various pituitary-hormone producing cells.

\section{ACKNOWLEDGEMENTS}

The authors are especially grateful to Mr. Dragan Ristić ("Laviefarm d.o.o., Belgrade, Serbia), Mr ph Maja Đurđević ("Yunycom", Belgrade, Serbia) and to Mr. Milan Jovanović ("Promedia d.o.o., Belgrade, Serbia) for financial support, as well as to Ivana Medigović, PhD (Department of Cytology, Institute for Biological Research "Siniša Stanković", Belgrade, Serbia) for technical support. This work was partially supported by the Ministry for Education, Science and Technological Development of the Republic of Serbia; Grant No. 173009.

\section{REFERENCES}

1. Besedowsky HO, del Rey A. Immune-neuro-endocrine interactions: facts and hypotheses. Endocr Rev 1996; 17(1): 64-102.

2. Denef C. Paracrinicity: the story of 30 years of cellular pituitary crosstalk. J Neuroendocrinol 2008; 20(1): 1-70.

3. Noda T, Kaidzu S, Kikuchi M, Yashiro T. Topographic affinities of hormone-producing cells in the rat anterior pituitary gland. Acta Histochem Cytochem 2001; 34(5): 313-9.

4. Stefaneanu L, Kovacs K. Changes in structure and function of the pituitary. Pathology of the aging rat. Aging 1994; 2: 173-91.

5. Ooka H. Proliferation of anterior pituitary cells in relation to aging and longevity in the rat. Zool Sci 1993; 10(5): 385-92.

6. vom Saal FS, Finch CE, Nelson JF (1994). Natural history and mechanisms of reproductive aging in humans, laboratory rodents, and other selected vertebrates. In: E. Knobil \& J. Neill (Eds.), The Physiology of Reproduction (pp. 861-1010). New York: Raven Press.

7. Weiss G, Skurnick JH, Goldsmith LT, Santoro NF, Park SJ. Menopause and hypothalamic-pituitary sensitivity to estrogen. JAMA 2004; 292(24): 2991-6.

8. Downs JL, Wise PM. The role of the brain in female reproductive aging. Mol Cell Endocrinol 2009; 299(1): 32-8.

9. Mercuri N, Petraglia F, Genazzani AD, Amato F, Sgherzi MR, Maietta-Latessa A, De Leo V, Nappi C, Genazzani AR. Hormonal treatments modulate pulsa- tile plasma growth hormone, gonadotrophin and osteocalcin levels in postmenopausal women. Maturitas 1993; 17(1): 51-62.

10. Sekulić $M$, Lovren M, Milošević V. Immunoreactive TSH cells in the pituitary of female middle-aged rats after Acta Histochem 1998 treatment with estradiol or calcium. Acta Histochem1998; 100(2): 185-91.

11. Milošević V, Starčević V, Šošić-Jurjević B, Filipović B, Trifunović S, Ristić N, Nestorović N, Manojlović M, Sekulić M. Effect of estradiol or calcium treatment on mammotrophs of female middle-aged rats. Acta Vet 2007; 57(5-6): 393-402.

12. Fournier A, Hill C, Clavel-Chapelon F. Hormone replacement therapy in menopause and risk of breast cancer. Bull Cancer 2003; 90(10): 821-31.

13. Prince RL. Counterpoint: Estrogen effects on calcitropic hormones and calcium homeostasis. Endocr Rev 1994; 15(3): 301-9.

14. Mobasseri S, Liebson PR, Klein LW. Hormone therapy and selective estrogen receptor modulators for prevention of coronary heart disease in postmenopausal women estrogen replacement from the cardiologist's perspective. Cardiol Rev 2004; 12(6): 287-98.

15. Lovren M, Sekulić M, Milošević V, Mićić M, Radulović N. Effects of estradiol and calcium on gonadotrophic cells in middle-aged female rats. Histochem J 1999a; 31(10): 671-6.

16. Lovren M, Sekulić M, Milošević V, Radulović N. Gonadotrophs in long-term ovariectomized rat females treated with luteinizing hormone releasing hormone and estradiol. Acta Vet 1999b; 49(2-3): 117-26.

17. Kostić N, Nestorović N, Negić N, Milošević V. (2003). The effects of estradiol on the morphofunctional characteristics of ACTH cells in middle-aged rats. In: Abstract book, $15^{\text {th }}$ European Congress of Clinical Chemistry and Laboratory Medicine, 1-5 June 2003 (pp. 1137-40). Barcelona, Spain, Monduzzi Editore S.p.A. - MEDIMOND Inc.

18. Milošević V, Trifunović S, Šošić-Jurjević B, Bujšić N, Sekulić M. Estradiol and calcium affect the growth hormone producing cells in female middle-aged rats. Acta Vet 2005; 55(2-3): 111-20.

19. Moordian AD. Mechanisms of age-related endocrine alterations. Drugs Aging 1993; 3(2): 81-146.

20. Martinoli MG, Ouellet J, Rheaume E, Pelletier G. Growth hormone and somatostatin gene expression in adult and aging rats as measured by quantitative in situ hybridiyation. Neuroendocrinology 1991; 54(6): 607-15.

21. Milošević V, Trifunović S, Ajdžanović V, Marković Z, Manojlović-Stojanoski M, Medigović I, Brkić B, Sekulić M. Immunopositive $\mathrm{GH}$ cells in long-term ovariectomized female rats treated with estradiol. Euro Med Lab 21. International Congress of Clinical Chemistry and Laboratory Medicine 15-19. May 2011 Berlin, Germany. Clinical Chem Lab Med 2011; 49(Special Supp.): s435.

22. Milošević V, Marković Z, Šošić-Jurjević B, Trifunović S, Ristić N, Brkić B, Ajdžanović V. Calcium recovers the 
growth hormone-producing cells in ovariectomized rats. 20st IFCC-EFLM European Congress of Clinical Chemistry and Laboratory Medicine, 19-23. 05. 2011, Milan, Italy. Biochimica Clin 2013; 37(Special Supp.): S317.

23. Lovren M, Sekulić M, Milošević V. Estradiol-induced changes in morphometric and functional parameters of gonadotrophic cells in middle-aged female rats. Med Sci Res 1996; 24(6): 379-81.

24. Horvath E, Kovacs K. Fine structural cytology of the adenohypophysis in rat and man. J Electron Microsc Tech 1988; 8(4): 401-32.

25. Wise PM. Female reproductive aging. Reproduction 1998; 29: 89-104.

26. Sekulić M, Lovren M, Popović T. Estradiol-induced changes in TSH-like immunoreactivity of pituitary cells in female rats. Experentia 1995; 51(4): 335-8.

27. Klug TL, Adelman RC. Evidence for a large thyrotropin and its accumulation during aging in rats. Biochem Biophys Res Commun 1977; 77(4): 1431-7.

28. Takahashi S, Miyatake M. Immuno-electron microscopical study of prolactin cells in the rat: postnatal development and effects of estrogen and bromocryptine. Zool Sci 1991; 8(3): 549-59.

29. Milošević V, Ajdžanović V, Šošić-Jurjević B, PopovskaPerčinić F, Sekulić M. (2005a). Comparative morphofunctional analyses of GH and PRL cells in middle-aged female rats after estradiol treatment. Clinica Veterinaria 3-7. September 2005 (pp. 364-6). Ohrid, FYR Macedonia: Proceedings "Clinica Veterinaria".

30. Kurosumi K, Kovama T, Tosaka H. Three types of growth hormone cells of the rat anterior pituitary revealed by immunoelectron microscopy using a colloidal gold antibody method. Arch Histol Jpn 1986; 49(2): 227-42.

31. Takahashi S. Heterogeneity and development of somatotrophs and mammotrophs in the rat. Zool Sci 1992; 9(5): 901-24

32. Sonntag W, Forman L, Miki N, Trapp J, Gottschall P, Meites J. L-dopa restores amplitude of growth hormone pulses in old male rats to the observed in young male rats. Neuroendocrinology 1982; 34(3): 163-18.

33. Craw MD, Spindler SR, Walford RL, Koizumi A. Agerelated decrease of growth hormone and prolactin gene expression in the mouse pituitary. Endocrinology 1987; 121(4): 1251-5.

34. Takahashi S, Gottschall P, Quigley K, Goya R, Meites J. Growth hormone secretory patterns in young, middleaged and old female rats. Neuroendocrinology 1987; 46(2): 137-42.

35. Pantić V. Biology of hypothalamic neurons and pituitary cells. International Review of Cytology 1995; 159: 1-112.

36. Takahashi S, Okazaki K, Kawashima S. Mitotic activity of prolactin cells in the pituitary glands of male and female rats of different ages. Cell Tissue Res 1984; 235(3): 497-502.

37. Itoh J, Kawai K, Serizawa A, Yamamoto Y, Ogawa K, Matsuno A, Watanabe K, Osamura R. Three-dimen- sional imaging of hormone-secreting cells and their microvessel environment in estrogen-induced prolactinoma of the rat pituitary gland by confocal laser scanning microscopy. Appl Immunohistochem Mol Morphol, 2001; 9(4): 364-70.

38. Takahashi S, Kawashima S. Proliferation of prolactin cells in rat: Effects of estrogen and bromocryptine. Zool Sci 1987; 4(2): 855-60.

39. Starčević V, Milošević V, Brkić B, Severs W. Effects of centrally applied somatostatin on pituitary adrenocorticotropes in female rats. Pharmacology 2000; 60(4): 203-7.

40. Horvath E, Kovacs K. Morphology of adenohypophyseal cells and pituitary adenomas. In: Imura H. (Eds.), Pituitary gland (pp. 26-62). New York: Raven press.

41. Hristić M, Kalafatić D, Marković V. 3H-thymidine incorporation in the pituitary cells and adrenocortical cells of rats treated with hydrocortisone during juvenile period. Arch Biol Sci 1989; 40 (1-4): 45-52.

42. Barnea A, Cho G, Porter JC. A reduction in the concentration of immunoreactivecorticotropin, melanotropin and lipotropin in the brain of the aging rat. Brain Research 1982; 232(2): 345-53.

43. Takahashi S, Oomizu S, Kobayashi Y. Proliferation of pituitary cells in streptozotocin-induced diabetic mice: effect of insulin and estrogen. Zool Sci 1994; 11: 445449 .

44. Keefer DA, Stumpf WE, Petrusz P. Quantitative autoradiographic assessment of $3 \mathrm{H}$-estradiol uptake immunocytochemically characterized pituitary cells. Cell Tissue Res 1976; 166(1): 25-35.

45. Lovren M, Sekulić M. Morphometric and functional changes of gonadotrophic cells in immature female rats treated with multiple estrogen doses. Jugoslov Med Biochem 1993; 12(1): 19-22.

46. Lovren M, Sekulić M, Milošević V, Mićić M, Radulović $\mathrm{N}$. Morphometric changes of gonadotropic cells in rat females treated with estradiol and calcium. Follia Anat 1998; 26 (Suppl. 1): 23-4.

47. Šošić-Jurjević B, Filipović B, Milošević V, Nestorović N, Sekulić, M. Effects of ovariectomy and chronic estradiol administration on pituitary-thyroid axis in adult rats. Life Sci 2006; 79(9): 890-987.

48. Kitay IJ. Effects of estradiol on pituitary-adrenal function in male and female rats. Endocrinology 1963; 72(1): 947-54.

49. Murai I, Ben-Jonathan N. Acute stimulation of prolactin release by estradiol: mediation by the posterior pituitary. Endocrinology 1990; 126(6): 3179-84.

50. Mukdsi J, De Paul A, Munoz S, Aoki A, Torres A. Immunolocalization of Pit-1 in gonadotroph nuclei is indicative of the transdifferention of gonadotroph to lactotroph cells in prolactinomas induced by estrogen. Histochem Cell Biol 2004; 121(6): 453-62.

51. Metka M, Holzer G, Raimann H, Heytmanek G, Hartmann B, Kurz C. The role of prolactin in the menopause. Maturitas 1994; 20(2-3): 151-4. 